\title{
PERTANGGUNGJAWABAN PIDANA PELAKU ORDERAN FIKTIF OJEK ONLINE YANG MENGAKIBAT KERUGIAN PT. GRAB INDONESIA ( STUDI PUTUSAN NOMOR 1507/PID.SUS/2018/PN.MDN)
}

\author{
Vikardin Waruwu, July Esther, Jusnizar Sinaga \\ Fakultas Hukum, Universitas HKBP Nommensen \\ julyesther@uhn.ac.id
}

\begin{abstract}
Abstrak
Konsep Pertanggungjawaban Pidana tidak hanya menyangkut soal hukum melainkan menyangkut nilai moral dan kesusilaan umum memenuhi keadilan. Pertanggungjawaban pidana didasarkan pada kesalahan pembuat bukan hanya dipenuhinya unsur tindak pidana dalam pertanggungjawaban pidana, beban pertangunggjawaban pidana dibebankan pada pelaku pelangaran tindak pidana, sehingga setiap orang yang melakukan pelangaran terhadap undang-undang wajib bertangungjawab atas apa yang telah dilakukannya. Metode penelitian yang digunakan dalam penulisan ini adalah penelitian hukum normatif dengan cara melakukan penelusuri atau menelaah bahan pustaka seperti buku, jurnal, dan Putusan Nomor 1507/Pid.Sus./2018/PN. Mdn. Hasil penelitian yang dilakukan maka diperoleh kesimpulan bahwa pertanggungjawaban pidana terdakwa Afandi Penampat Perangin-angin memiliki kemampuan bertanggungjawab dan adanya kesalahan yang dilakukan yang bertentangan dengan hukum sehingga hakim menjatuhkan pidana terhadaap terdakwa dengan Pasal 30 Ayat (3) Jo Pasal 46 Ayat (3) Undang-Undang Nomor 11 Tahun 2008 Tentang Informasi dan Transaksi Elektronik sebagaimana diperbaharui dengan Undang-Undang Nomor 19 Tahun 2016 Tentang Perubahan Atas Undang-Undang Nomor 11 Tahun 2008 Tentang Informasi dan Transaksi Elektronik Jo Pasal 55 Ayat (1) Ke-1 KUHPidana
\end{abstract}

\section{Kata kunci: Pertanggungjawaban Pidana, Orderan Fiktif, Kerugian}

\begin{abstract}
The concept of criminal responsibility does not only concern legal matters but also concerns moral values and general morals to fulfill justice. Criminal liability is based on the fault of the maker, not only the fulfillment of the elements of a criminal act in criminal responsibility, the burden of criminal responsibility is borne by the perpetrator of a criminal offense, so that everyone who violates the law is obliged to be responsible for what he has done. The legal research method used in this research is normative legal research which is used by tracing or analyzing library materials such as books, journals, and decision Number 1507 / Pid.Sus. / 2018 / PN. Mdn. Based on the research conducted, it was found that the criminal responsibility of the defendant Afandi Penampat Peranginangin has the ability to be responsible and there are mistakes that are against the law so that the judge convicted the defendant under Article 30 Paragraph (3) Jo Article 46 Paragraph (3) of Law Number 11 Of 2008 concerning Electronic Information and Transactions as updated by Law Number 19 of 2016 concerning Amendments to Law Number 11 of 2008 concerning Electronic Information and Transactions Jo Article 55 Paragraph (1) 1st of the Criminal Code
\end{abstract}

Keywords, Criminal Liability, Fictional Order, Losses 
PATIK : JURNAL HUKUM Vol : 09 No. 3, Desember 2020, Hal 174 - 190

\section{Pendahuluan}

Negara Indonesia adalah Negara Hukum, penegasan sebagai negara hukum tercantum pada pasal 1 ayat (3) Undang-undang Dasar Negara Republik Indonesia Tahun 1945. Konsekuensi sebagai negara hukum adalah kehidupan bernegara harus berdasarkan hukum. Selanjutnya dalam pasal 27 ayat (1) Undang-undang Dasar Negara Republik Indonesia Tahun 1945 ditegaskan bahwa, "segala warga negara bersamaan kedudukannya di dalam hukum dan pemerintah dan wajib menjujung hukum dan pemerintah itu dengan tidak ada kecualinya". Konsekuesnsi dari ketentuan ini adalah setiap warga negara apapun strata sosialnya mendapat keadilan dalam hukum dan pemerintah. ${ }^{1}$

Manusia sebagai makhluk sosial memiliki banyak kebutuhan yang harus dipenuhi untuk memenuhi kebutuhannya. Kebutuhan tersebut dimungkinkan tidak dapat terpenuhi dalam satu wilayah saja. Dalam rangka memenuhi kebutuhan tersebut manusia memerlukan transportasi untuk melakukan aktivitasnya seperti melakukan perpindahan orang atau barang dari satu tempat ke tempat yang lain dengan menggunakan kendaraan. Apabila dilihat dari karakteristik jenis moda transportasi dapat dibedakan menjadi kendaraan pribadi dan kendaraan umum. Kendaraan pribadi adalah kendaraan yang dioperasionalkan hanya untuk orang yang memiliki kendaraan tersebut. Kendaraan umum adalah kendaraan yang disediakan untuk dipergunakan oleh umum dengan memungat biaya, kendaraan umum dapat dikategorikan menjadi kendaraan yang disewakan (paratransit) dan kendaraan umum biasa (transit).

Transportasi juga dikategorikan setua dengan peradaban manusia dimaksud bahwa transportasi atau kegiatan memindahkan (mengangkut) barang dari suatu tempat ke tempat lain itu sudah dilaksanakan sejak dahulu kala, sejak manusia hidup didunia. Sarana yang digunakan untuk mengangkut barang pada jaman dahulu bersifat sangat sederhana dan tradisional yaitu berjalan kaki, menjinjing dengan tangan, menjunjung diatas kepada, menggunakan pikulan. Setelah ditemukan roda dibuatkan gerobak yang ditarik oleh manusia, kemudian dikembangkan dengan moda transportasi oleh manusia. ${ }^{2}$

Moda transportasi sepeda motor termasuk dalam klasifikasi jenis kendaraan pribadi (private), tetapi di Indonesia banyak dijumpai sepeda motor yang juga melakukan fungsi sebagai kendaraan umum yaitu mengangkut orang dan memungut biaya yang disepakati, Moda transportasi jenis ini terkenal dengan nama Ojek. Kemajuan Teknologi Informasi sekarang dan kemungkinannya di masa yang akan datang tidak lepas dari dorongan yang dilakukan oleh perkembangan Teknologi Komunikasi dan Teknologi Komputer, Kemajuan Teknologi inilah yang mendukung terciptanya moda Transportasi Online di Indonesia.

Seiring dengan kemajuan Teknologi Informasi tersebut saat ini terdapat fenomena Transportasi yang cukup menyita perhatian masyarakat, yaitu moda Transporatasi berbasis aplikasi atau Online yang pada saat ini dikelola oleh Perusahaan Berbadan Hukum yaitu Grab Indonesia. Fenomena ojek Online kini makin digemari, sebab angkutan Transporatasi Online ini mempunyai karakteristik yaitu efisiensi dalam hal waktu, cara pemesaran, mampu melayani pada saat diperlukan, daya jelajahnya cukup tinggi, dan memiliki ciri khas tersendiri yaitu menggunakan atribut berupa helem dan jeket berwarna hijau dengan logonya sendiri.

${ }^{1}$ Simamora, Janpatar., Tafsir Makna Negara Hukum dalam Perspektif Undang-Undang Dasar Negara Republik Indonesia Tahun 1945, Jurnal Dinamika Hukum FH Universitas Jenderal Soedirman, Vol. 14 No. 3 September 2014, hlm. 547-561

${ }^{2}$ Saksi Adji adisasmita, Transporatasi Komprehensif dan Multi Moda, Graha Ilmu, Makassar, 2012, hal. 13 
Mengikuti perkembangan ojek saat ini, telah berkembang menjadi mata pencaharian yang menjanjikan dengan bergabung ojek Online kita akan memiliki penghasilan tambahan dan tidak terikat waktu kerja. Keberadaan Transportasi Online ini sebagai bentuk pemenuhan kebutuhan (demand) masyarakat akan angkutan dengan operasional pelayanan seperti ojek ternyata belum memiliki payung hukum, oleh karena itu banyak pihak dalam kaitannya dengan transaksi dan keberadaan Transportasi Online ini belum mendapat perlindungan hukum.

Keberadaan moda transportasi Online tersebut di Indonesia yang dikelola oleh Grab Indoneisa memiliki sistem yang dikelola oleh Badan Usaha tersebut yang berbentuk aplikasi dimana aplikasi tersebut dimasukkan ke dalam sistem Smartphone dan Aplikasi tersebut menjadi acuan bagi calon pengguna jasa (Konsumen) dan juga bagi pekerja (Driver) untuk menjalankan bidang jasa yang dikelola oleh Grab Indonesia tersebut.

Namun kenyataannya, sistem yang dikelola pada Perusahaan Transportasi Online yang berupa aplikasi pada Smartphone tersebut memiliki kekurangan. Kekurangan pada sistem tersebut salah satunya pekerja (Driver) pada Grab Indonesia tersebut bisa melakukan Orderan Fiktif (Penipuan) serta terdata dalam aplikasi dan sistem yang dikelola oleh Badan Usaha tersebut sehingga para pekerja (Driver) tersebut selalu seolah olah bekerja melakukan pengangkutan jasa sesuai yang diinginkan perusahaan. Akibatnya, Orderan Fiktif tersebut mengakibatkan kerugian bagi Perusahaan.

Seiring dengan kemajuan Teknologi Informasi tersebut pemerintah telah membuat Undang-undang yang mengatur tentang kejahatan Orderan Fiktif (Penipuan) yang dimana aturan Perundang-undangan tersebut telah diterapkan dalam Pasal 30 ayat (3) Jo Pasal 46 ayat (3) Undang-undang Nomor 11 Tahun 2008 Tentang Informasi dan Transaksi Elektronik sebagaimana diperbaharui dengan Undang-undang Nomor 19 Tahun 2016 Tentang Perubahan Undang-undang Nomor 11 Tahun 2008 Tentang Informasi dan Transaksi Elektronik Jo Pasal 55 Ayat (1) Ke-1 KUHPidana.

\section{Tinjauan Pustaka}

Dalam bahasa Inggris pertanggungjawaban pidana disebut sebagai responsibility, atau criminal liabiliyy. Konsep pertanggungjawaban pidana sesungguhnya tidak hanya menyangkut soal hukum semata-mata melainkan juga menyangkut soal nilai-nilai moral atau kesusilaan umum yang dianut oleh suatu masyarakat atau kelompok-kelompok dalam masyarakat, hal ini dilakukan agar pertanggungjawaban pidana itu dicapai dengan memenuhi keadilan.

Pertanggungjawaban pidana adalah mengenakan hukuman terhadap pembuat karena perbuatan yang melanggar larangan atau menimbulkan keadaan yang terlarang. Pengertian perbuatan yang dapat dihukum yang perlu dipahami, yakni konsep tentang melawan hukum dan konsep tentang delik atau tindak pidana. Perbuatan dari melawan hukum inilah dianggap sebagai unsur dari setiap tindak pidana. ${ }^{3}$

Pertanggungjawaban pidana terjadi karenanya menyangkut proses peralihan hukuman yang ada pada tindak pidana kepada pembuatnya. Mempertanggungjawabkan seseorang dalam hukum pidana adalah meneruskan hukuman yang secara objektif ada pada perbuatan pidana secara subjektif terhadap pembuatnya.

Pertanggungjawaban pidana ditentukan berdasarkan pada kesalahan pembuat dan bukan hanya dengan dipenuhinya seluruh unsur tindak pidana. Menurut moelyatno

\footnotetext{
${ }^{3}$ Siswanto Sunarso, Penegakan Hukum Psikotropika dalam Kajian Sosiologi Hukum, Raja Grafindo Persada, Jakarta, 2004, Hal. 41
} 
Pertanggungjawaban Pidana adalah kemampuan untuk membedakan antara perbuatan yang baik dan buruk seta mampu menentukan kehendak menurut keinsyafan baik atau buruk. ${ }^{4}$

Pertanggungjawaban pidana merupakan penilaian yang dilakukan setelah dipenuhinya seluruh unsur tindak pidana atau terbuktinya tindak pidana. ${ }^{5}$ Pertanggungjawaban (pidana) menjurus kepada pemidanaan petindak, jika telah melakukan suatu tindak pidana dan memenuhi unsur-unsurnya yang telah ditentukan dalam undang-undang. ${ }^{6}$

Dalam pertanggungjawaban pidana maka beban pertanggungjawaban dibebankan kepada pelaku pelanggaran tindak pidana berkaitan dengan dasar untuk menjatuhkan sanksi pidana. Seseorang akan memiliki sifat pertanggungjawaban pidana apabila suatu hal atau perbuatan yang dilakukan olehnya bersifat mnelawan hukum, namun seseorang dapat hilang sifat bertanggungjawabnya apabila di dalam dirinya ditemukan suatu unsur yang menyebabkan hilangnya kemampuan bertanggungjawab seseorang.

Pada hakikatnya pertanggungjawaban pidana adalah suatu bentuk mekanisme yang diciptakan untuk berekasi atas pelanggaran suatu perbuatan tertentu yang disepakati. Unsur kesalahan merupakan unsur utama dalam pertanggungjawaban pidana. Dalam pengertian perbuatan tindak pidana tidak termasuk hal pertanggungjawaban pidana, perbuatan pidana hanya menunjuk kepada apakah perbuatan tersebut melawan hukum atau dilarang oleh hukum, mengenai apakah seseorang yang melakukan tindak pidana tersebut kemudian dipidana tergantung kepada apakah seseorang yang melakukan perbuatan pidana tersebut memiliki unsur kesalahan atau tidak.

Adanya pertanggungjawaban pidana dibebankan kepada pelaku maka pelaku pidana harus dipidana. Tidak adanya pikiran yang salah (no guilty mind) berarti tidak ada pertanggungjawaban pidana dan berakibat tidak dipidananya pembuat kesalahan sebagai bagian mensrea juga diartikan sebagai kesalahan karena melanggar aturan, atau melanggar tata peraturan perundang-undangan.

Setiap orang yang melakukan pelanggaran terhadap undang-undang maka orang tersebut wajib bertanggungjawab atas apa yang telah dilakukan. Kesalahan sebagai unsur pertanggungjawaban dalam pandangan ini menjadikan suatu jaminan bagi seseorang dan menjadikan kontrol terhadap kebebasan seseorang terhadap orang lain. Adanya jaminan ini menjadikan seseorang akan terlindung dari perbuatan orang lain yang melakukan pelanggaran hukum, dan sebagai suatu control karena setiap orang yang melakukan pelanggaran hukum pidana dibebani pertanggungjawaban pidana.

Penipuan dalam KUHP merupakan terminologi dalam hukum pidana, yang diataur dalam Buku ke II (Tentang Kejahatan) dalam Bab XXV Pasal 378 KUHP, dinyatakan: "barangsiapa dengan maksud untuk menguntungkan diri sendiri atau orang lain secara melawan hukum, dengan memakai nama hukum palsu atau martabat palsu, dengan tipu muslihat, atau martabat palsu, dengan tipu muslihat, atau rangkaian kebohongan, menggerakkan orang lain untuk menyerahkan barang sesuatau kepadanya atau supaya memberi utang maupun menghapuskan piutang, diancam karena penipuan dengan pidana penjara paling lama empat tahun.

Dalam Pasal 378 KUHP tentang penipuan (bedrong), terdapat dua unsur pokok yaitu, Unsur “objektif” dan "subjektif".

\section{Unsur Objektif}

${ }^{4}$ Adami Chazawi, Hukum Pidana Bagian I, Raja Grafindo, Jakarta, 2013, Hal. 148

5 Agus Rusianto, Tindak Pidana dan Pertanggungjawaban Pidana, Prenamedia, Jakarta, 2016, Hal.

${ }^{6}$ S.R Sianturi, Asas-Asas Hukum Pidana Di Indonesia dan Penerapannya, Gunung Mulia, Jakarta, 1996, Hal. 244 
Unsur Objektif yaitu membujuk/menggerakan orang lain dengan alat pembujuk/penggerak:
a. Memakai nama palsu;
b. Martabat/keadaan palsu;
c. Rangkaian kata bohong, tipu muslihat;
d. Menyerahkan sesuatu barang;
e. Membuat utang;
f. Menghapus piutang;

2. Sengaja atau Kesengajaan

Sengaja mengandung unsur 'subjektif', yaitu dengan maksud: menguntungkan diri sendiri atau orang lain; dengna melawan hukum. Berkenaan kesengajaan (dolus/opzet) atau kealpaan (kulpa), dari rumusan kesalahan (sculd) tersebut di atas merupakan suatau kesalahan dalam bentuk kesengajaan (opzettelijik/dolus), tidak dalam bentuk kesengajaan (culpa).

Dalam hukum positif indonesia, defenisi tentang kesengajaan belum ada yang memberikan defenisi tentang kesengajaan. Defenisi kesengajaan yang tepat dijumpai dalam Werboek van Strafrect 1809. Yaitu: "kesengajaan adalah kehendak untuk melakukan atau tidak melakukan perbuatan-perbuatan yang dilarang atau diharuskan oleh undang-undang. Dalam teori juga dikenal ada beberapa benuk untuk modal kesengajaan yaitu:

a. Kesengajaan sebagai maksud;

b. Kesengajaan sebagai kepastian, keharusan;

c. Kesengajaan dengan kemungkinan (dolus eventualis).

Sama halnya dengan delik pencurian dan penggelapan (Pasal 362 dan 372 KUHP), maka Pasal 378 KUHP juga merupakan delik pokok yang jika ditambah dengan satu atau lebih bagian inti lagi, pidanannya bertambah untuk delik tercantum dalam Pasal 379 dan 379 a. ${ }^{7}$ Bagian inti delik (delicts bestanddelen) penipuan :

a. Dengan maksud untuk menguntungkan diri sendiri atau orang lain;

b. Secara melawan hukum;

c. Dengan memakai nama palsu atau martabat palsu, dengan tipu muslihat, ataupun dengan rangkaian perkataan bohong;

d. Menggerakkan orang lain;

e. Untuk menyerahkan suatau barang kepadanya atau untuk memberi utang ataupun menghapus piutang.

Jadi, ada maksud untuk menguntungkan diri sendiri atau orang lain, yang berarti di sini ada kesengajaan sebagai maksud (cogmerk). Perbuatan itu dilakukn secara melawan hukum, artinya antara lain dia tidak mempunyai hak untuk menikmati keutungan itu. Memakai nama palsu misalnya mengaku suatu nama yang dikenal baik oleh orang yang ditipu. Martabat palsu misalnya mengaku sebagai kyai, dengan tipu muslihat misalnya mengaku akan membelikan barang yang sangat murah kepada orang yang ditipu. Rangkaian kebohongan artinya banyak, pokoknya kebohongan itu maksudnya sebagai upaya penipuan. Oleh karena itu, menurut Nico Keijzer kepada penulis, delik yang paling tepat untuk orang mengutak-atik komputer untuk mendapatkan keutungan ialah Pasal 378 ini.

\footnotetext{
${ }^{7}$ Yahman, Karateristik Wanprestasi Dan Tindak Pidana Penipuan, Prenadamedia Grup, Jakarta, 2014, Hal. 112
} 


\section{PATIK : JURNAL HUKUM Vol : 09 No. 3, Desember 2020, Hal 174 - 190}

Pidana bagi delik penipuan adalah pidana penjara maksimum empat tahun tanpa alternatif denda. Jadi, delik penipuan dipandang lebih berat dari pada delik penggelapan karena pada delik penggelapan ada alternatif denda. Oleh karena itu, penuntut umum yang menyusun dakwaan primair dan subsidiar kedua pasal ini harus mencantumkan delik penipuan pada dakwaan primair, sedangkan dakwaan subsidiair ialah penggelapan.

Menurut Cleiren delik penipuan adalah delik dengan adanya akibat (gevolgsdelicten) den delik berbuat (gedragsdelicten) atau delik komisi. Umumnya delik dalam kecurangan adalah dengan akibat (gevolgsdelicten) dan delik dengan berbuat (gedragsdelicten). Pembuat undang-undang memandang delik penipuan adalah delik kecurangan yang paling penting. Rumusan delik penipuan sudah beberapa kali diubah di Belanda. Di belakang kata-kata "menggerakkan orang lain memberikan suatau barang" ada kata-kata "untuk menguasai data yang mempunyai nilai uang dalam lalu lintas perdangan. ${ }^{8}$

Selain KUHP yang memuat aturan yang terkait dengan penipuan terdapat juga atauran yang secara khusus mengatur mengenai tindak pidana cybercrime yaitu Undangundang Nomor 11 Tahun 2008 Tentang Informasi dan Tranksaksi Elektronik, dalam Undang-undang ini telah dibahas menganai hal-hal yang berkaitan dengan informasi elektronik, transaksi elektronik, dan mengatur juga mengenai hal-hal yang dilarang berkaitan dengan "dunia maya" beserta ancaman pidananya. Didalam Undang-undang ITE tidak menyebutkan secara jelas apa yang dimaksud dengan penipuan, akan tetapi terhadap penipuan jual beli melalui sistem Online itu sendiri kita dapat melihatnya melalui pasalpasal yang terdapat dalam Undang-undang ITE, salah satunya Pasal 28 ayat (1) UU ITE dengan melihat terpenuhinya unsur-unsur pidana yang ada. Walaupun dalam pasal 28 ayat (1) UU ITE tidak mengatur secara jelas mengenai tindak pidana penipuan itu sendiri namun terkait dengan timbulnya kerugian Konsumen yang menyatakan "secara tanpa hak menyebarkan berita bohong dan menyesatkan yang mengakibatkan kerugian konsumen dalam Transaksi Elektronik." Kata "Berita Bohong" dan "Menyesatkan" dan dalam pasal 28 ayat (1) UU ITE dapat disetarakan dengan kata "tipu muslihat atau rangkaian kebohongan" dapat disimpulkan bahwa pasal 28 ayat (1) UU ITE merupakan perluasan dari tindak pidana penipuan secara konvesional, atau tindak pidana penipuan yang terjadi di dalam masyarakat.

Tindak pidana merupakan suatu fenomena sosial yang sering terjadi didalam masyarakat, fenomena ini akan terus ada seiring dengan pertumbuhan perkembangan zaman. Umumnya tindak pidana dilakukan atas dasar untuk memenuhi kebutuhan hidup yang relatif sulit dipenuhi dengan cara yang mudah. Hal ini menunjukkan semakin tingginya intelektualitas dari pelaku kejahatan dan didukung pula oleh perkembangan ilmu pengetahuan dan teknologi informasi (IPTEK) yang sangat berpengaruh besar terhadap perubahan perilaku dan hukum dalam masyarakat. Kejahatan juga menjadi bagian dari hasil budaya itu sendiri, hal ini berarti semakin tinggi tingkat kebudayaan dan semakin modern suatu bangsa, maka semakin modern pula kejahatan itu dalam bentuk, sifat dan cara pelaksanaannya.

Pengertian order fiktif adalah suatu tindakan pemesanan Gojek yang dilakukan oleh driver, seolah-olah mengantarkan seorang pelanggan, driver menggunakan dua ponsel dengan dua aplikasi di dalamnya, di satu ponsel ia berperan sebagai pelanggan, dan dipinsel lainnya berperan sebagai drivernya. Tindakan ini semata mata bertujuan mendapatkan bonus yang besar karena aplikasi akan merekam jumlah pelanggan yang

\footnotetext{
${ }^{8}$ Jur Andi Hamzah, Delik-Delik Tertentu (Speciale Delicten) Di Dalam KUHP, Sinar Grafika, Jakarta, 2018, Hal. 110
} 
diantarkan oleh driver. Semakin banyak record pelanggan, semakin besar bonus yang didapatkan.

Teknologi informasi dan komunikasi saat ini cenderung banyak memberikan kemudahan bagi manusia, salah satunya dapat dilihat dari kemudahan penggunaan internet. Peran internet sangat penting bagi masyarakat, melalui internet kita dapat mengetahui dan melakukan berbagai hal. Namun demikian, perkembangan teknologi informasi dan komunikasi dapat menimbulkan dampak positif dan nampak negatif. Salah satu dampak positif dari perkembangan teknologi informasi dan komunikasi adalah munculnya jasa transportasi berbasis Online yang menggunakan internet. Jasa transportasi Online merupakan salah satu bisnis yang sedang berkembang saat ini di indonesia. Transportasi Online sebagai layanan yang memudahkan masyarakat dalam melakukan mobilitas perjalanan, jasa transportasi Online yang ada yaitu taksi Online dan ojek Online. Transportasi Online menggunakan teknologi smarphone untuk menghubungkan konsumen dengan driver yang tersedia di dekat posisi konsumen. Dengan adanya bisnis transportasi Online Ini tidak hanya menguntungkan konsumen melainkan juga menguntungkan driver.

Pengertian tindak pidana dalam memalsukan data grab online adalah setiap perbuatan terhadap perusahaan jasa pengemudi, yang berakibat timbulnya kesengajaan yang berakibat timbulnya kesengsaraan termasuk ancaman untuk melakukan perbuatan, pemaksaan, atau perampasaan kemerdekaan secata melawan hukum dalam lingkup pribadi dan komunikasi (Undang-undang No. 19 tahun 2016 tentang perubahan atas UU No. 11 tahun 2008 tentang Informasi dan transaksi Elektronik).

Cybercrime adalah sebuah perbuatan yang tercela dan melanggar kepatutan di dalam masyarakat serta melangar hukum sekalipun sekarang masih sukar menemukan norma hukum yang secara khusus mengatur cybercrime. Oleh karena itu peran masyarakat untuk menentukan sifat dapat dicela dan melanggar kepatutan di masyarakat dari suatu perbuatan cybercrime. ${ }^{9}$ Banyak kasus-kasus perbankan baik diluar negeri maupun indonesia yang mencuat akibat dari ulah para penjahat cyber ini. Cepat mencuat karena bidang perbankan adalah tempat transaksi jalur perdangangan dan jalur perekonomian yang dipergunakan oleh masyarakat bayak, begitu jaringan komputer sebuah bank tersebut di-hack maka akan lumpuh perputaran uang yang terjadi di bank tersebut atau bahkan dapat berpengaruh pada perekonomian sebuah negara pada saat itu. ${ }^{10}$

Perbuatan orderan fiktif yang dilakukan oleh driver Ojek Online dapat dikategorikan sebagai tindak penipuan. Berdasarkan pasal 35 undang-undang nomor 11 tahun 2008 tentang informasi dan transaksi elektronik maka perbuatan hukum (legal action) yang dilakuan oleh pelaku dengan tindakan orderan fiktif maka memenuhi semua unsur delik tindak pidana didalam pasal tersebut, sehingga subyek hukum pelaku orderan fiktif bisa dipidana dengan di junctokan kedalam pasal 51 undang-undang nomor 11 tahun 2008 tentang informasi dan transaksi elektronik.

Dilihat dari semua unsur-unsur Pasal 378 KUHP maka tindakan subyek hukum pelaku dalam perbuatan orderan fiktif memenuhi semua unsur dalam pasal tersebut. Pasal 378 KUHP berbunyi, barang siapa dengan maksud hendak menguntungkan diri sendiri atau orang lain dengan melawan hak, baik dengan memakai nama palsu atau keadaan palsu, baik dengan akal dan tipu muslihat, maupun dengan karangan perkataan-perkataan bohong, membujuk orang supaya memberikan sesuatu barang, membuat utang atau mengapuskan piutang, dihukum karena penipuan, dengan hukuman penjara selama-lamnya empat tahun.

\footnotetext{
${ }^{9}$ Dikdik M. Arief Mansur, Cyberlaw, Refika Aditama, Bandung, 2009, Hal. 89

${ }^{10}$ Bidi Suhariyanto, Tindak Pidana Teknologi Informasi, Cytra Adytia, Semarang, 2016, Hal. 78
} 
Tindak pidana Driver yang melakukan Orderan fiktif sebagaimana melanggar Undang-undang nomor 19 tahun 2016 tentang informasi dan transaksi elektronik juga dikategorikan pada tindak pidana khusus. Tindak pidana khusus pada umumnya dapat pemberatan. Maksud diperberatnya pidana pada dasar pemberatan pidana khusus ini ialah pada si pembuat dapat dipidana melampaui atau diancaman maksimum pada pidana yang bersangkutan. Hal sebab diperberatnya mana dicantumkan secara tegas dalam dan mengenai tindak pidana tertentu tersebut. Disebut dasar pemberatan khusus, karena hanya berlaku pada tindak pidana tertentu yang dicantumkan alasan pemberatannya itu saja dan tidak berlaku pada tindak pidana lain. ${ }^{11}$

Driver adalah subjek hukum yang dapat bertanggungjawab penuh, sehingga telah memenuhi unsur "Barangsiapa". Unsur "dengan maksud hendak menguntungkan diri sendiri atau orang lain dengan melawan hak", dalam KUHP R. Soesilo dijelaskan sebagai menguntungkan diri sendiri dengan tidak berhak. Tindakan ordera fiktif membut driver memperoleh bonus lebih banyak dan bukan merupakan haknya.

Unsur selanjutnya yang dipenuhi yaitu "dengan memakai nama palsu atau keadaan palsu". Dalam hal ini driver bertindak seolah-olah sebagau pelanggan, membuat identitas palsu serta memanipulasi keadaan seolah-olah mengantarkan pelanggan. Oleh karena itu driver yang melakukan tindakan order fiktif dapat dijerat dengan pasal penipuan serta terancam hukuman penjara maksimal selama 4 tahun.

\section{Metode}

Jenis penelitian yang dipergunakan adalah yuridis normatif yaitu penelitian yang dilakukan berdasarkan bahan hukum utama dengan cara menelah teori, konsep, asas serta peraturan perundang-undangan. Penelitian ini mengutamakan studi kepustakaan yaitu dengan mempelajari buku-buku, peraturan perundang-undangan, literatur-literatur dan serta membedah kasus yang berhubungan dengan pokok pembahasan penelitian. Pendekatan-pendekatan yang digunakan dalam penelitian hukum adalah pendekatan undang-undang (statute approach), pendekatan kasus (case approach), pendekatan historis (historical approach), pendekatan komparatif (comparative approach), dan pendekatan konseptual (conceptual approach). ${ }^{12}$ Adapun sumber bahan hukum peneliti, maka sesuai dengan sifat penelitian yang bersifat yuridis normatif maka sumber bahan hukum yang digunakan adalah sumber bahan hukum sekunder dapat dibagi atas tiga bagian yaitu:

a) Data Primer

Data primer merupakan bahan hukum yang bersifat mengikat, seperti Undang-undang Republik Indonesia Nomor 11 Tahun 2008 Tentang Informasi dan Transaksi Elektronik, Kitab Undang-undang Hukum Pidana (KUHP), Kitab Undang-undang Hukum Acara Pidana (KUHAP) dan Putusan Pengadilan Nomor 1507/Pid.Sus/2018/PN.Mdn.

b) Data Sekunder

Data Sekunder adalah bahan hukum yang memberi penjelasan lebih lanjut mengenai bahan hukum primer, seperti buku-buku dan jurnal.

c) Data Tersier

Data tersier adalah bahan hukum yang dapat menunjang keterangan dari bahan hukum primer dan sekunder seperti kamus hukum.

${ }^{11}$ Adami Chazawi, Pelajaran Hukum Pidana Bagian II, Raja Grafindo Persada, Jakarta, 2002, Hal.

${ }^{12}$ Peter Mahmud Marzuki, Penelitian Hukum, Prenada Media, Jakarta, 2005, hal. 93 
Bahwa dia terdakwa Afandi Penampar Perangin-Angin bersama-sama dengan Amiruddin Mendrofa, Douglas Dapot Hutabarat, Dedy Setiawan Mendrofa, Douglas Dapot Agustinus Ginting, Yos Andry Ginting, Kristindo Simamora, Saewoendi Sembiring (masing-masing perkara terpisah). Pada hari senin tanggal 19 Februari 2018 sekitar pukul 20.00 wib, atau setidak-tidaknya pada suatu waktu lain pada bulan februari 2018 ataupun setidak-tidaknya pada suatu waktu lain dalam tahun 2018, di jalan Melati Raya Medan tepatnya di Warung Gondong atau setidak-tidaknya pada suatu tempat yang masih termasuk dalam daerah hukum Pengadilan Negeri Medan, "yang melakukan, yang menyuruh melakukan, dan turut serta melakukan perbuatan dengan sengaja dan tanpa hak atau melawan hukum mengakses Komputer dan/atau Sistem Elektronik dengan cara apapun dengan melanggar, menerobos, melampaui atau menjebol system pengamanan, perbuatan tersebut dilakukan terdakwa dengan cara sebagai berikut:

Bahwa berawal pada hari Senin tanggal 19 Februari 2018 sekitar pukul 20.00 wib, ketika itu saksi D.P Rumapea dan saksi Zainal Arifin Hasibuan bersama dengan team saksi dari Kepolisian Polrestabes Medan ada mendapat informasi yang layak dipercaya bahwasanya ada beberapa orang Supir Grab yang diduga sebagai Pelaku yang telah melakukan Orderan Fiktif terhadap system aplikasi Grab milik PT. Solusi Transpotasi Indonesia sedang berkumpul dijalan Melati Raya Medan tepatnya di Warkop Gondrong menanggapi hal tersebut saksi-saksi langsung melakukan pengecehkan kelokasi dan setiba di Warkop Gondrong tersebut saksi-saksi melihat 8 (delapan) orang sedang berkumpul dengan gerak gerik yang mencurigakan dan setelah melakukan penyelidikan saksi-saksi diketahui 8 (delapan) orang yang masing-masing terdakwa Afandi Penampar PeranginAngin bersama-sama dengan Amiruddin Mendrofa, Douglas Dapot Hutabarat, Dedy Setiawan Mendrofa, Douglas Dapot Agustinus Ginting, Yos Andry Ginting, Kristindo Simamora, Saewoendi Sembiring beserta seluruh barang bukti untuk diserahkan ke Polrestabes Medan. Selanjutnya terdakwa Afandi Penampat Perangin-angin, Amiruddin Mendrofa, Douglas Dapot Hutabarar, Dedy Setiawan Ginting, Agustinus Ginting, Yos Andry Ginting, Kristiando Ginting, Sarwoedi Sembiring mengakui bahwasanya terdakwa Afandi Penampat Perangin-angin, Amiruddin Mendrofa, Douglas Dapot Hutabarat, Dedy Setiawan Ginting, Agustinus Ginting, Yos Andry Ginting, Kristiando Simamora adalah adalah Mitra Grab yang berkerja sebagai supir Grab Milik PT. Solusi Transportasi Indoneia dan telah melakukan penyalah gunaan data melalui transaksi elektronik terhadap sistem aplikasi grab milik PT. Solusi Transportasi Indoneisa dengan cara didalam system handphone yang digunakan sebagai akun Driver Grab telah di rooting (jebol system serifikat/licensed handphonenya) dan juga telah menginstal 5 (lima) aplikasi ilegal diantaranya Kingroot, Super Su, Satpol PP, BSH MAP dan MOCK LOCATION (FAKE GPS) untuk mengelabuhi/ menipuan GPS system operator GRAB CAR resmi dengan tujuan agar dalam melakukan aktifitas Grab tanpa bekerjapun seolah-olah ada mendapatkan orderan penumpang asli dan hal tersebut telah terdakwa lakukan secara berulang-ulang untuk mencapai dan mendapatkan uang jaminan/bonus dari PT. Solusi Transportasi Indonesia, sedangkan terhadap Sarwoedi Sembiring adalah sebagai orang yang melakukan rooting (jebol system sertifikat/licensed handphone) masing-masing handphone akun driver grab dimana cara mereset handphone Sarwoedi Sembiring dengan menginstal terlebih dahulu 5 (lima) aplikasi ilegal diantaranya KINGROOT, SUPER SU, SATPOL PP, BSH MAP DAN MOCK LOCATION (FAKE GPS) menggunkan laptop merek Acer warna hitam milik SARWOENDI SEMBIRING.

Akibat perbuatan terdakwa Afandi Penampat Perangin-angin, Amiruddin Mendrofa, Douglas Dapot Hutabaray, Dedy Setiawan Ginting, Agustinus, Yos Andry 
Ginting, Kristiando Simamora, Sarwoedi Sembiring, PT. Solusi Transportasi Indonesia mengalami kerugian yaitu:

1. Terdakwa Afandi Penampat Hutabarat Peranging-angin, sebesar Rp. 655.00.(enam ratus lima puluh lima rupiah) sebagaimana data perjalanan fiktif yang masuk ke system PT. Solusi Transportasi Indonesia.

2. Douglas Dapot Hurabat sebesar Rp. 401.600.- (empat ratus satu ribu enam ratus rupiah) sebagaimana data perjalanan fiktif yang masuk ke system PT. Solusi Transportasi Indonesia.

3. Amiruddin Mendrofa sebesar Rp. 1.286.800.- (satu juta dua ratus delapan puluh enam delapan ratus rupiah) sebagaimana data perjalanan fiktif yang masuk ke system PT. Solusi Transportasi Indonesia.

4. Dedy Setiawan Ginting sebesar Rp. 1.343.800.- (satu juta tidaratus empat puluh tiga ribu delapan ratus rupiah) sebagaimana data perjalanan fiktif yang masuk ke system PT. Solusi Transportasi Indonesia.

5. Agustinus Ginting sebesar Rp. 2.721.400.- (dua juta tujuh ratus duapuluh satu ribu empat ratus rupiah) sebagaimana data perjalanan fiktif yang masuk ke system PT. Solusi Transportasi Indonesia.

6. Yos Andry Ginting sebesar Rp. 520.800.- (lima ratus duapuluh ribu delapan ratus rupiah) sebagaimana data perjalanan fiktif yang masuk ke system PT. Solusi Transportasi Indonesia.

7. Kristianodi Simamora sebesar Rp. 83.000.- (delapan puluh tiga ribu rupiah) sebagaimana data perjalanan fiktif yang masuk ke system PT. Solusi Transportasi Indonesia.

\section{Dakwaan}

Sesuai dengan kronologis kasus tersebut diatas terdakwa Afandi Penampat Peranginn Angin di dakwa oleh penuntut umum dengan dakwaan yang bersifat Alternatif:

1. Perbuatan terdakwa sebagaimana diatur dan diancam pidana dalam Pasal 30 Jo Ayat (3) Jo Pasal 46 Atau (3) UU No.11 Tahun 2008 Tentang Informasi dan Transaksi Elektronik sebagaimana diperbaharui dengan UU No. 19 Tahun 2016 Tentang Perubahan Atas UU No.11 Tahun 2008 Tentang Informasi dan Transaksi Elektronik Jo Pasal 55 Ayat (1) Ke-1 KUHPidana.

2. Perbuatan terdakwa sebagaimana diatur dan diancam pidana dalam Pasal 32 Ayat (2) Jo Pasal 48 Ayat (2) UU No.11 Tahun 2008 Tentang Informasi dan Transaksi Elektronik sebagaimana diperbaharui dengan UU No. 19 Tahun 2016 Tentang Perubahan Atas UU No.11 Tahun 2008 Tentang Informasi dan Transaksi Elektronik Jo Pasal 55 Ayat (1) Ke-1 KUHPidana.

3. Perbuatan terdakwa sebagaimana diatur dan diancam pidana dalam Pasal 35 Jo Pasal 51 Ayat (1) UU No.11 Tahun 2008 Tentang Informasi dan Transaksi Elektronik sebagaimana diperbaharui dengan UU No. 19 Tahun 2016 Tentang Perubahan Atas UU No.11 Tahun 2008 Tentang Informasi dan Transaksi Elektronik Jo Pasal 55 Ayat (1) Ke-1 KUHPidana.

4. Perbuatan terdakwa sebagaimana diatur dan diancam pidana dalam Pasal 378 KUHPidana Jo Pasal 55 Ayat (1) Ke-1 KUHPidana.

\section{Tuntutan}

Jaksa Penuntut Umum menuntut agar terdakwa di jatuhi hukuman yang amarnya sebagai berikut:

1. Menyatakan Terdakwa Afandi Penampat Perangin Angin bersalah melakukan tindak pidana "Yang melakukan, yang menyuruh melakukan, dan yang turut serta melakukan perbuatan dengan sengaja dan tanpa hak atau 
melawan hukum mengakses Komputer dan/atau Sistem Elektronik dengan cara apapun dengan melanggar, menerobos, melampaui atau menjebol system pengamanan" sebagaimana diatur dalam Dakwaan Pertama melanggar Pasal 30 ayat (3) Jo Pasal 46 Ayat (3) UU No. 11 Tahun 2008 Tentang Informasi dan Transaksi Elektronik sebagaimana diperbaharui dengan UU No. 19 Tahun 2016 Tentang Perubahan atas UU No. 11 Tahun 2008 Tentang Informasi dan Transaksi Elektronik Jo Pasal 55 Ayat (1) Ke-1 KUHPidana.

2. Menjatuhkan pidana terhadap Terdakwa oleh karena itu dengan pidana penjara selama 10 (sepuluh) bulan dikurangi selama terdakwa ditahan dengan perintah agar terdakwa tetap ditahan.

3. Menyatakan barang bukti berupa:

a. 9 (Sembilan) data perjalanan fiktif yang dilakukan oleh para mitra pengemudi Grab PT Solusi Transportasi Indonesia yaitu Agustinus Ginting, Amiruddin Mendrofa yang memakai 2 akun an. Mantius Mendrofa, Douglas Dapot Hutabarat, Yos Andry Ginting, Afandi Penampat Perangin-angin, Dedy Stiawan Ginting, Kristinoso Simamora dan Sonlius Tekap Ginting.

b. 1 (satu) buah flashdisk yang berisikan data perjalan fiktif dan dokumen identitas para mitra pengemudi Grab PT. Solusi Transprotasi Indonesia berikut data kerugian PT. Solusi Transprotasi Indonesia.

c. 1 (satu) unit HP Merk Lenovo A6000 Nomor Sim card 081375113921 nomor imei 867804026408481.

d. 1 (satu) unit HP Merk Evercross Nomor sim card 083193312191 nomor imei 357350061860324.

e. 1 (satu) unit HP Merk Mito nomor sim card 083139712163 nomor imei 359689063699786 / 359689063699794.

f. 1 (satu) unit HP Merk Mito nomor sim card 083189621154 nomor imei $359788065005081 / 359788065005099$.

g. 1 (satu) unit HP Merk Ever Cross nomor sim card 085756361650 nomor imei 35850705058850.

h. 1 (satu) unit HP Merk Polytron nomor sim card 083189621150 nomor imei 354882054418200 / 354882055297140.

i. 1 (satu) unit HP Merk Polytron nomor sim card 083125455639 nomor imei 354882054418200 / 354882055297330.

j. 1 (satu) unit HP Ever Cross Mito nomor sim card 0831421831424 nomor imei 35672106411147.

k. 1 (satu) unit HP Merk Polytron nomor imei 354882054471746 / 354882055243607.

1. 1 (satu) unit HP Merk Alcatel nomor imei 358786074213390 / 354882055243607.

m. 1 (satu) unit Mobil Toyota avanza warna hitam BK 1731 VO.

n. 1 (satu) buah kartu ATM CIMB Niaga.

4. Menetapkan agar terdakwa dibebani membayar biaya perkara sebesar Rp.5.000,- (Lima ribu rupiah).

\section{Putusan}

1. Menyatakan terdakwa AFANDI PENAMPAT PERANGIN-ANGIN telah terbukti secara Sah dan meyakinkan bersalah melakukan tindak pidana "Yang melakukan, yang menyuruh melakukan, dan yang turut serta melakukan perbuatan dengan sengaja dan tanpa hak atau melawan hukum mengakses 
Komputer dan/atau Sistem Elektronik dengan cara apapun dengan melanggar, menerobos, melampaui atau menjebol system pengamanan.

2. Menjatuhkan pidana terhadap terdakwa AFANDI PENAMPAT PERANGIN-ANGIN tersebut dengan pidana penjara selama 6 (enam) bulan.

3. Menetapkan masa penangkapan dan penahanan yang telah dijalani oleh terdakwa, dikurangkan seluruhnya dari pidana yang dijatuhkan.

4. Memerintahkan agar terdakwa tetap ditahan.

5. Menyatakan barang bukti berupa:

a. 9 (Sembilan) data perjalanan fiktif yang dilakukan oleh para mitra pengemudi Grab PT Solusi Transportasi Indonesia yaitu Agustinus Ginting, Amiruddin Mendrofa yang memakai 2 akun an. Mantius Mendrofa, Douglas Dapot Hutabarat, Yos Andry Ginting, Afandi Penampat Perangin-angin, Dedy Stiawan Ginting, Kristinoso Simamora dan Sonlius Tekap Ginting.

b. 1 (satu) buah flashdisk yang berisikan data perjalan fiktif dan dokumen identitas para mitra pengemudi Grab PT. Solusi Transprotasi Indonesia berikut data kerugian PT. Solusi Transprotasi Indonesia.

c. 1 (satu) unit HP Merk Lenovo A6000 Nomor Sim card 081375113921 nomor imei 867804026408481.

d. 1 (satu) unit HP Merk Evercross Nomor sim card 083193312191 nomor imei 357350061860324.

e. 1 (satu) unit HP Merk Mito nomor sim card 083139712163 nomor imei 359689063699786 / 359689063699794.

f. 1 (satu) unit HP Merk Mito nomor sim card 083189621154 nomor imei $359788065005081 / 359788065005099$.

g. 1 (satu) unit HP Merk Ever Cross nomor sim card 085756361650 nomor imei 35850705058850.

h. 1 (satu) unit HP Merk Polytron nomor sim card 083189621150 nomor imei 354882054418200 / 354882055297140.

i. 1 (satu) unit HP Merk Polytron nomor sim card 083125455639 nomor imei 354882054418200 / 354882055297330.

j. 1 (satu) unit HP Ever Cross Mito nomor sim card 0831421831424 nomor imei 35672106411147.

k. 1 (satu) unit HP Merk Polytron nomor imei 354882054471746 / 354882055243607.

1. 1 (satu) unit HP Merk Alcatel nomor imei 358786074213390 / 354882055243607.

m. 1 (satu) unit Mobil Toyota avanza warna hitam BK 1731 VO.

n. 1 (satu) buah kartu ATM CIMB Niaga.

6. Membebankan biaya perkara kepada terdakwa sejumlah Rp. 5.000,00 (lima ribu rupiah).

Setelah menguraikan kasus diats maka analisis pertanggungjawaban pidana pelaku orderan fiktif ojek Online yang mengakibatkan kerugian perusahaan PT. Grab Indonesia di pengadilan Negeri Medan (Putusan Nomor 1507/Pid.Sus/2018/PN.MDN) yaitu:

Dalam pengertiannya dakwaan adalah surat atau akte yang memuat perumusan dari tindak pidana yang didakwakan, yang sementara dapat disimpulkan dari hasil penyidik, 
surat dakwaan merupakan dasar bagi hakim untuk melakukan pemeriksaan di sidang pengadilan. Dan berikut jenis-jenis dakwaan;

a. Dakwaan Tunggal

Dakwaan tunggal ialah terdakwa didakwa dengan satu perbuatan saja, tanpa diikuti dengan dakwaan-dakwaan lain atau tanpa alternatif dakwaan lainya. Dakwaan ini jarang digunakan, dakwaan ini digunakan untuk kasus yang sangat sederhana karena resikonya yang besar. Jika dakwaan tidak dapat dibuktikan, maka terdakwa dibebaskan.

b. Dakwaan Alternatif

Dakwaan alternatif ialah terdakwa didakwa dengan lebih dari satu tindak pidana, tetapi pada hakikatnya ia hanya didakwa atau dipersalahkan dengan satu tindak pidana saja. Dakwaan ini digunakan atau dibuat apabila penuntut umum ragu atau meragukan yang mana yang terbukti dipengadilan.

c. Dakwaan Subsidair

Sama halnya dengan dakwaan alternatif, dimana terdakwa didakwa dengan lebih dari satu tindak pidana, tetapi pada prinsipnya terdakwa hanya dipersalahkan satu tindak pidana saja. Jika salah satu dakwaan terbukti, maka dakwaan lainnya tidak perlu diperiksa. Dalam dakwaan ini diurutkan memeriksa dakwaan secara berurutan, dari dakwaan primer atau terberat, dan jika terbukti hakim memeriksa dakwaan selanjutnya, sehingga yang terakhir adalah yang terakhir.

d. Dakwaan Kumulatif

Terdakwa didakwakan dengan beberapa tindak pidana sekaligus, dan tindak pidana tersebut harus diperiksa keseluruhannya, karena tindak pidana tersebut merupakan tindak pidana yang berdiri sendiri.

e. Dakwaan Campuran

Dakwaan ini merupakan gabungan dari dakwaan kumulatif, alternatif, subsidair. Jadi, disamping didakwakan dengan dakwaan kumulatif, terdakwa juga masih didakwakan dengan dakwaan alternatif dan subsidair.

Apabila dilihat dari jenis-jenis surat dakwaan diatas dikaitkan dengan surat dakwaan Jaksa Penuntut Umum yang diajukan dipersidangan untuk terdakwa maka, jenis surat dakwaan yang diajukan oleh Jaksa Penuntut Umum yaitu surat dakwaan yang berbentuk alternatif.

Dakwaan alternatif ialah terdakwa didakwa dengan lebih dari satu tindak pidana, tetapi pada hakikatnya ia hanya didakwa atau dipersalahkan dengan satu tindak pidana saja. Oleh karena itu Penulis sangat sependapat dengan bentuk dakwaan yang bersifat alternatif yang diajukan oleh Jaksa Penuntut Umum tersebut, dikarenakan Jaksa Penuntut Umum masih ragu atau meragukan pasal mana yang akan dijatuhkan terhadap terdakwa, sehingga Jaksa Penuntut Umum harus menguji pasal yang diancamkan dalam dakwaan berdasarkan keterangan saksi, keterangan terdakwa, barang bukti dan fakta-fakta yang terungkap dalam persidangan.

Berdasarkan uraian tersebut diatas Jaksa Penuntut Umum akan menyimpulkan Pasal mana yang unsur-unsurnya terpenuhi dan dijatuhkan terhadap terdakwa untuk mempertanggungjawabkan perbuatannya, yang akan dimuat oleh Jaksa Penuntut Umum didalam tuntutannya. 
Tuntutan yang diberikan jaksa penuntut umum terhadap terdakwa Afandi Penampat Perangin-Angin yang menuntut terdakwa dengan pidana penjara selama 10 (sepuluh) bulan sehingga penulis memberikan pendapat tidak setuju dengan tuntuntan pidana penjara selama 10 (sepuluh) bulan kepada terdakwa dikarenakan bentuk perjanjian antara PT. Solusi Transportasi Indonesia dengan Driver Grabnya bentuk kemitraan sehingga pidana penjara 10 (sepuluh) bulan yang dituntut oleh Jaksa Penuntut Umum terhadap terdakwa tidak sebanding dengan akibat hukum yang ditimbulkan oleh perbuatan terdakwa dimana perbuatan terdakwa telah melanggar janji kemitraan serta perbuatan terdakwa membuat PT. Solusi Transportasi Indonesia menjadi buruk citranya yang akan mengurangi kepercayaan konsumen terhadap PT. Solusi Transportasi Indonesia.

Pasal 30 Ayat (3) Jo Pasal 46 Ayat (3) UU No 11 Tahun 2008 Tentang Informasi dan Transaksi Elektronik sebagaimana diperbaharui dengan UU No 19 Tahun 2016 Tentang Perubahan Atas UU No 11 Tahun 2008 Tentang Informasi dan Transaksi Elektronik Jo Pasal 55 Ayat 1 Ke-1 KUHPidana, yang merupakan Pasal yang dituntut oleh Jaksa Penuntut Umum terhadap terdakwa merumuskan pidana penjara yang dijatuhkan terhadap pelanggar pasal tersebut diatas paling lama 8 (delapan) Tahun dan/atau denda paling banyak 800.000.000 (delapan ratus juta rupiah). Merujuk dalam ketentuan tersebut apa yang telah dituntut oleh Jaksa Penuntut Umum telah jauh dari apa yang diamanatkan oleh undang-undang dan tidak sesuai dengan 2/3 tuntutan Jaksa Penuntut Umum. Bila merujuk pada ketentuan 2/3 tuntutan Jaksa Penuntut Umum seharusnya terdakwa dituntut dengan pidana penjara selama 4 Tahun.

Tuntutan pidana penjara selama 4 Tahun berdasarkan 2/3 tuntutan yang diberikan terhadap terdakwa dapat dikatakan sesuai dengan tindak pidana yang dilakukan oleh si terdakwa dan memberikan efek jera baginya, sehingga pelaku tindak pidana tersebut merasakan penderitaan secara fisik dan dengan cara tersebut terdakwa tidak akan mengulanginya kembali perbuatan tindak pidana.

Berdasarkan fakta-fakta hukum didalam persidangan bahwa terdakwa telah memenuhi unsur-unsur pertanggungjawaban pidana yaitu:

\section{Mampu Bertanggungjawab}

Didalam KUHP tidak ada ketentuan tentang arti kemampuan bertanggungjawab tetapi didalam KUHP terdapat ketentuan yang mengatur unsur ketidak mampuan bertanggungjawab yaitu didalam Pasal 44 KUHP mengatakan bahwa " Barang siapa melakukan perbuatan yang tidak dapat dipertanggungjawabkan kepadanya karena jiwanya cacat dalam pertumbuhan atau terganggu karena penyakit tidak dipidana. Untuk dapat dipertanggungjawabkan kepadanya maka harus memenuhi unsur kemampuan bertanggungjawab yaitu:

Suatu kemampuan berfikir (psychis) pada pembuat yang memungkinkan pembuat menguasai pikirannya dan menentukan kehendaknya.

1. Pembuat dapat mengerti makna dan akibat kelakuannya.

2. Pembuat dapat menentukan kehendaknya sesuai dengan pendapatnya tentang makna dan akibat kelakukannya.

3. Mampu mengerti maksud perbuatannya.

4. Mampu menyadari bahwa perbuatannya tidak dapat dibenarkan oleh masyarakat.

5. Mampu menentukan kehendak dalam melakukan perbuatannya. 
Berdasarkan fakta dalam persidangan terbukti bahwa benar terdakwa Afandi Penampat Perangin-Angin telah melakukan tindak pidana sebagaimana didakwakan oleh jaksa penuntut umum. Terdakwa melakukannya dalam keadaan sehat jasmani maupun rohani. Sehingga atas perbuatannya dapat dimintai pertangunggjawaban pidana sebagaimana diatur didalam Pasal 30 Ayat (3) Jo Pasal 46 Ayat (3) UU No. 11 Tahun 2008 Tentang Informasi dan Transaksi Elektronik sebagaimana diperbaharui dengan UU No. 19 Tahun 2016 Tentang Perubahan atas UU No. 11 Tahun 2008 Tentang Informasi dan Transaksi Elektronik Jo Pasal 55 Ayat (1) Ke-1 KUHP.

\section{Kesalahan}

Asas tiada pidana tanpa kesalahan (Belanda; geen straf zonder schuld) yang menunjukan bahwa seseorang hanya dapat dihukum atas perbuatannya apabila pada dirinya terdapat kesalahan.

Adapun fakta-fakta dalam persidangan mengenai kasus tersebut diatas telah terbukti bahwa terdakwa Afandi Penampat Perangin-Angin telah melakukan perbuatan dengan sengaja dan tanpa hak atau melawan hukum mengakses komputer dan/atau Sistem Elektronik dengan cara apapun dengan melanggar, menerobos, melampaui, atau menjebol sistem pengamanan.

Berkenan dengan unsur kesalahan yaitu harus melakukan perbuatan pidana. Berdasarkan fakta-fakta dipersidangan dan memperhatikan fakta-fakta hukum tersebut diatas memilih langsung dakwaan Alternatif Kesatu Pasal 30 Ayat (3) Jo Pasal 46 Ayat (3) UU No. 11 Tahun 2008 Tentang Informasi dan Transaksi Elektronik sebagaimana diperbaharui dengan UU No. 19 Tahun 2016 Tentang Perubahan atas UU No. 11 Tahun 2008 Tentang Informasi dan Transaksi Elektronik Jo Pasal 55 Ayat (1) Ke-1 KUHP.

Unsur-unsurnya adalah sebagai berikut:

1. Setiap Orang

Menimbang, bahwa unsur "Setiap Orang" dalam perkara ini menunjukan kepada terdakwa Afandi Penampat Perangin-Angin yang dalam persidangan telah mengakui secara jelas dan nyata Identitasnya sebagaimana tercantum dalam surat dakwaan Penuntut Umum dan tidak ada kesalahan tentang orangnya. Dengan demikian unsur ke 1 "Setiap Orang" telah terpenuhi dan terbukti secara Sah dan menyakinkan menurut hukum.

2. Yang melakukan, yang menyuruh melakukan, dan turut serta melakukan perbuatan dengan sengaja dan tanpa hak atau melawan hukum mengakses Komputer dan/atau Sistem Elektronik dengan cara apapun dengan melanggar, menerobos, melampaui, atau menjebol sistem pengamanan.

Bahwa terdakwa Afandi Penampat Perangin-Angin telah terbukti melakukan penyalah gunaan data melalui Tranksaksi Elektronik terhadap sistem Aplikasi Grab milik PT. Solusi Transportasi Indonesia. Dengan demikian maka unsur Ke 2 "yang melakukan, yang menyuruh melakukan, dan turut serta melakukan perbuatan dengan sengaja dan tanpa hak atau melawan hukum mengakses Komputer dan/atau Sistem Elektronik 
dengan cara apapun dengan melanggar, menerobos, melampaui, atau menjebol sistem pengamanan" telah terpenuhi secara Sah dan meyakinkan.

Putusan Hakim adalah putusan yang didasarkan dengan pertimbangan hukum sesuai fakta yang terungkap di persidangan, sesuai undang-undang dan keyakinan hakim tanpa terpengaruh dari berbagai intervensi Esksternal dan Internal sehingga dapat dipertanggungjawabkan secara professional kepada public (the truth and justice).

Dalam memutuskan pidana terhadap terdakwa hakim harus berdasarkan pada minimal dua alat bukti yang Sah kemudian dua alat bukti tersebut Hakim memperoleh keyakinan bahwa tindak pidana yang didakwakan benar-benar terjadi dan terdakwalah yang melakukannya. Hal tersebut diatur dalam Pasal 183 KUHAP dan juga dalam Pasal 193 Ayat (1) KUHAP jika pengadilan berpendapat bahwa terdakwa bersalah melakukan tindak pidana yang didakwakan kepadanya, maka pengadilan menjatuhkan pidana.

Dalam Putusan No. 1507/Pid.Sus/2018/PN.Mdn Proses pengambilan keputusan oleh Majelis Hakim berdasarkan fakta-fakta hukum yang berdiri atas keterangan saksi, keterangan terdakwa serta barang bukti. Sehingga Majelis Hakim dapt memutuskan pidana terhadap terdakwa Afandi Penampat Perangin-Angin dengan dakwaan Alternatif kesatu Pasal 30 Jo Ayat (3) Pasal 46 Ayat (3) UU No. 11 Tahun 2008 Tentang Informasi dan Transaksi Elektronik sebagaimana diperbaharui dengan UU No. 19 Tahun 2016 Tentang Perubahan Atas UU No. 11 Tahun 2008 Tentang Informasi dan Transaksi Elektronik Jo Pasal 55 Ayat (1) Ke-1 KUHPidana. yaitu dengan pidana penjara selama 6 (enam) bulan dan masa penagkapan dan penahanan yang telah dijalanin oleh terdakwa, dikurangkan seluruhnya dari pidana yang dijatuhkan.

Dalam putusan Majelis Hakim tersebut diatas penulis tidak setuju dengan pidana yang telah dijatuhkan kepada terdakwa tersebut, karena menurut penulis pidana penjara yang dijatuhkan terhadap terdakwa Afandi Penampat Perangin-Angin tidak memberikan efek jera bagi pelaku tindak pidana orderan fiktif ojek Online yang mengakibatkan kerugian perusaan PT. Grab Solusi Transportasi Indonesia.

\section{Kesimpulan Dan Saran}

Pertanggungjawaban pidana pelaku orderan fiktif ojek Online yang mengakibatkan kerugian perusahaan PT. Grab Indonesia (Studi Putusan Nomor 1507/Pid.Sus/2018/PN.Mdn).Bahwa berdasarkan dari unsur pertanggungjawaban pidana, terdakwa Afandi Penampat Perangin-angin adalah mampu bertanggungjawaban dalam perbuatannya yang bertentangan dengan hukum. Sehingga berdaasarkan dengan faktafakta hukum dalam persidangan bahwa terdakwa mempunyai bentuk kesalahan yaitu yang melakukan, yang menyuruh melakukan, dan yang turut serta melakukan perbuatan dengan sengaja dan tanpa hak atau melawan hukum mengakses komputer dan/atau Sistem Elektronik dengan cara apapun dengan melanggar, menerobos, melampaui, atau menjebol sistem pengamanan

Sebaiknya hukuman yang melakukan tindak pidana orderan fiktif jangan hanya dikenakan pidana penjara tetapi juga harus dikenakan pidana denda sehingga dapat memberikan ganti rugi terhadap perusahaan PT. Grab Indonesia.

\section{DAFTAR PUSTAKA}

\section{Buku dan Jurnal}


PATIK : JURNAL HUKUM Vol : 09 No. 3, Desember 2020, Hal 174 - 190

Adji Adisasmita, Saksi, Transportasi Komprehensif dan Multi Moda. Makassar: Graha Ilmu, 2012

Anggusti, M. and Anggusti, Y. (2020) "PENEGAKAN HUKUM DI INDONESIA DALAM RANGKA TATA KELOLA PEMERINTAHAN YANG LEBIH BAIK MENUJU 100 TAHUN KEMERDEKAAN INDONESIA (2045)", Nommensen Journal of Legal Opinion, 1(01), pp. 38-52. doi: 10.51622/njlo.v1i01.37.

Arief, Barda Nawawi, Kebijakan Hukum Pidana, Semarang: Kencana Media Grup. 2018

Chazawi, Adami, Hukum Pidana Bagian I. Jakarta: Raja Grafindo, 2013

Chazawi, Adami, Pelajaran Hukum Pidana Bagian I, Jakarta, Rajawali Press, 2008

Chazawi, Adami, Pelajaran Hukum Pidana Bagian II. Jakarta: Raja Grafindo, 2002

Hamzah, Andy, Asas-Asas Hukum Pidana. Jakarta: Rineka Cipta, 2008

Hamzah, Jur Andy, Delik-Delik Tertentu (Speciale Delicten) Di DalamKUHP. Jakarta, S Sinar Grafika 2018

Kansil, C.S.T, Pokok-Pokok Hukum Pidana. Jakarta, Pradnia Paramita, 2013

Mansur, Dikdik M. Mansur. Cyberlaw. Bandung: Refika Aditama, 2009

Makarim, Edmon, Notaris \& Transaksi Elektronik. Jakarta: Raja Grafindo, 2003

Marzuki, Peter Mahmud, Penelitian Hukum. Jakarta: Prenada Media, 2005

Prakoso, Djoko, Masalah Pemberian Pidana Dalam Teori Dan Praktek Peradilan. Jakarta: Ghalia Indonesia, 1999

Rusianto, Agus, Tindak Pidana Dan Pertanggungjawaban Pidana. Jakarta: Prenamedia, 2016

R.M, Suharto, Hukum Pidana Materiil. Yogyakarta, Sinar Grafika, 1991

Simamora, Janpatar., Tafsir Makna Negara Hukum dalam Perspektif Undang-Undang Dasar Negara Republik Indonesia Tahun 1945, Jurnal Dinamika Hukum FH Universitas Jenderal Soedirman, Vol. 14 No. 3 September 2014, hlm. 547-561.

Sianturi, S.R, Asas-Asas Hukum Pidana Di Indonesia dan Penerapannya. Jakarta, Gunung Mulia, 2016

Suhariyanto, Budi, Tindak Pidana Teknologi Informasi. Semarang: Citra Adytia. 2013

Suhariyanto, Budi. 2014. Tindak Pidana Teknologi Informasi. Jakarta: Raja Grafindo.

Sunarso, Siswanto, Penegakan Hukum Psikotropika Dalam Kajian Sosiologi Hukum. Jakarta, Raja Grafindo, 2004

Yahman, Karateristik Wanprestasi Dan Tindak Pidana Penipuan, Jakarta, Prenada Media, 2014 